Secher, K. 1976: Airborne radiometric survey between $66^{\circ}$ and $69^{\circ} \mathrm{N}$, southern and central West Greenland. Rapp. Grønlands geol. Unders. 80, 65-67.

Secher, K. 1979: A new topographic and geological map of an area south-west of Søndre Strømfjord. Medd. Inst. landmåling fotogrammetri 10, 182-185.

Secher, K. 1980a: Distribution of radioactive mineralisation in central West Greenland. Rapp. Grønlands geol. Unders. 100, 61-65.

Secher, K. 1980b: Indhold af lanthanider i karbonatitbjergarter fra Sarfartôq karbonatitkomplekset, centrale Vestgrønland, bestemt ved instrumentel neutronaktiveringsanalyse (INAA). Unpubl. int. GGU report, $13 \mathrm{pp}$.

Secher, K. \& Larsen, L. M. 1978: A new Phanerozoic carbonatite complex in southern West Greenland. Rapp. Grønlands geol. Unders. 90, 46-50.

Secher, K. \& Larsen, L. M. 1980: Geology and mineralogy of the Sarfartôq carbonatite complex, southern West Greenland. Lithos, 13(2), 199-212.

Thorning, L. 1976: Aeromagnetic surveys in southern and central West Greenland between $63^{\circ}$ and $71^{\circ}$ N. Rapp. Grønlands geol. Unders. 80, 61-65.

Thorning, L. 1977: Continuation of the aeromagnetic surveys in southern and central West Greenland between $64^{\circ}$ and $72^{\circ}$ N. Rapp. Grønlands geol. Unders. 85, 34-37.

Thorning, L. 1980: A system of computer programs for the processing and interpretation of aeromagnetic data. Unpubl. int. GGU report, $58 \mathrm{pp}$.

\title{
A minor carbonatite occurrence in southern West Greenland: the Tupertalik intrusion
}

\section{Lotte Melchior Larsen and Asger Ken Pedersen}

In addition to the two large carbonatite complexes of Cambrian age occurring in southern West Greenland, the Sarfartô and Qaqarssuk complexes (Secher \& Larsen, 1980; Gothenborg \& Pedersen, 1975) a third small intrusion of carbonatite was found in 1971 during regional prospecting by Kryolitselskabet Øresund A/S. This intrusion is situated approximately $50 \mathrm{~km}$ east of the town Sukkertoppen, only $11 \mathrm{~km}$ north-north-west of the Qaqarssuk complex of which it may be regarded as a satellite (fig. 13). The outcrop measures only $500 \mathrm{~m}$ by $200 \mathrm{~m}$. It is situated on a gently south-east sloping, relatively vegegation covered hillside in a depression between $800 \mathrm{~m}$ and $1000 \mathrm{~m}$ high mountains, the most prominent of which is Tupertalik ('the place with a tent') after which the intrusion is named.

Mainly due to its small size the intrusion has not received much attention. GGU samples collected during short visits there included rock types different from those found in the Sarfartôq and Qaqarssuk complexes, and among these were samples of sky-blue lapis lazuli. During the 1981 field season the intrusion was mapped in detail with a plane table. A map at a scale 1:1000 was produced; a simplified and interpreted version is presented in fig. 14 . 


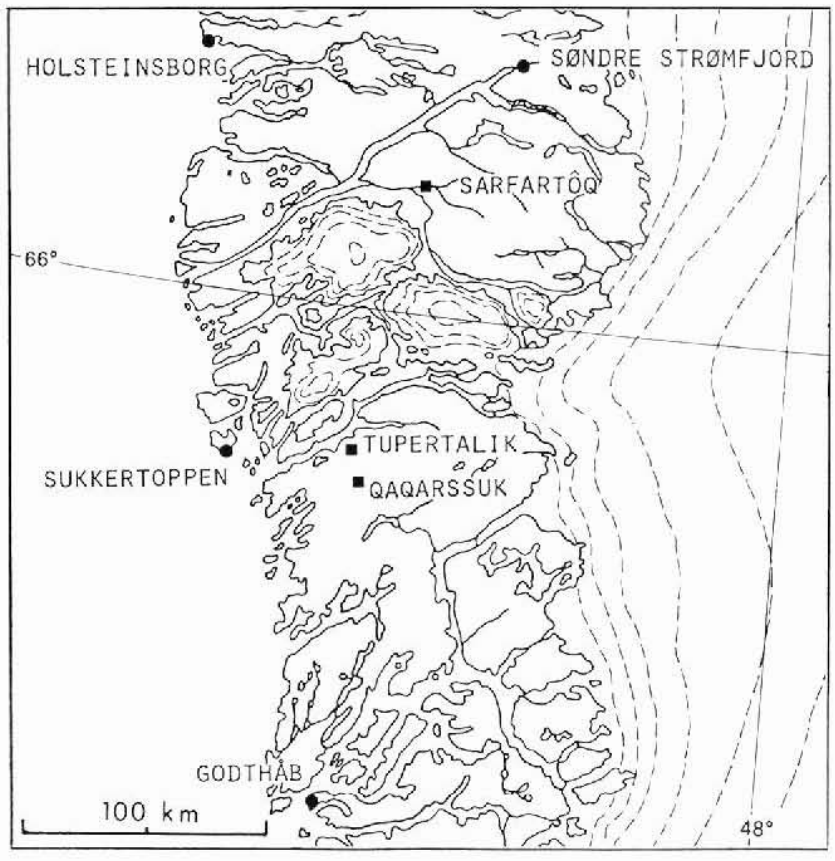

Fig. 13. The location of the Tupertalik intrusion in relation to the two other known carbonatite complexes in southern West Greenland.

\section{Structure}

The intrusion has a relatively simple structure. It is emplaced as a comformable sheet into an open, gently SW-plunging synform fold in the gneiss (fig. 14). The general orientation of the fold axis is $224^{\circ}$, plunge $5^{\circ}$. The rather irregular outcrop as seen on the map is due to the frequent occurrence of roof remnants still covering the slightly wavy carbonatite sheet. These 'waves' have amplitudes of 2 to $6 \mathrm{~m}$, large enough to be recognisable on the map and in the profiles (fig. 14). These irregularities at least partly originate from similar structures in the gneiss. Though on a large scale the intrusion is conformable it shows many small-scale discordant relations. Country rock xenoliths of all sizes may be found in the carbonatite, and cross-cutting carbonatite veins are found in the country rock. There are, however, no signs of explosive activity in the form of shattering and breccia formation.

As seen from the profiles in fig. 14 the carbonatite at the present level of erosion can be interpreted as a sheet of approximately $10 \mathrm{~m}$ thickness, still partly covered by roof remnants, and with the bottom exposed along the outer margin and, due to topography effects, also along the shore of the lake (stippled boundary due to very scattered exposures). The possibility that the 'roof remnants' are actually macro-xenoliths in an even thicker carbonatite sheet (?) cannot, however, be excluded. The original lateral extent of the intrusion is also open to question. There is little doubt that it continues south-westwards beneath the lake and that its root zone is situated there. Reconnaissance along the shores of the 700 by $1000 \mathrm{~m}$ large lake showed no signs of further carbonatite occurrences. 


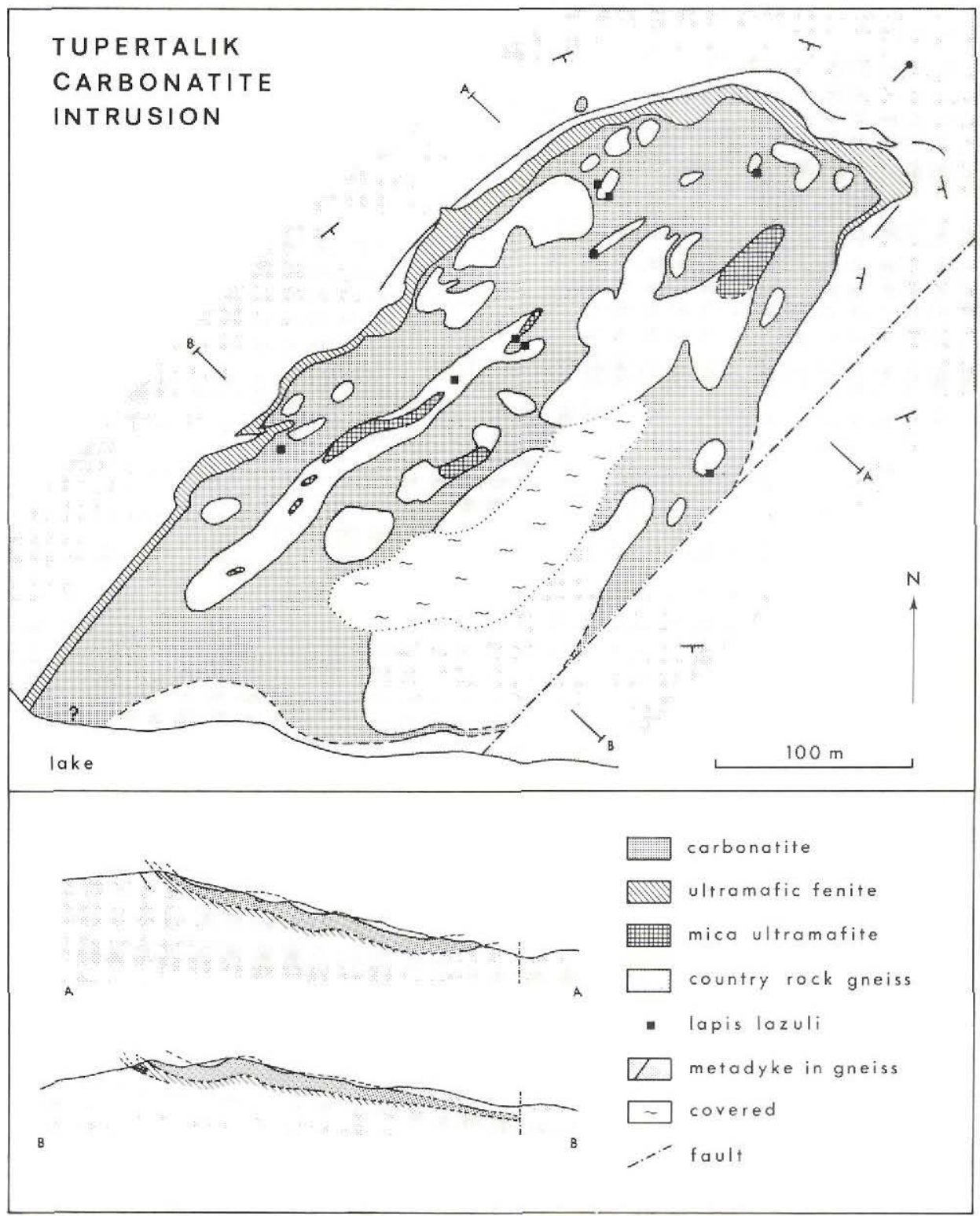

Fig. 14. Simplified map of the Tupertalik carbonatite intrusion. The profiles are drawn to the same scale as the map, with no vertical exaggeration. 
A major vertical fault with the regional direction $44^{\circ} \mathrm{NE}$ has removed the outermost part of the south-east flank of the carbonatite sheet (fig. 14). The missing part is small and has not been located.

\section{The country rock}

Within a few hundred metres from the intrusion the country rock is dominantly leucocratic gneiss with scattered bands of several generations of meta-igneous amphibolites. Two prominent zones (2-10 m wide) are found consisting of amphibolite and lherzolitic ultramafic rocks, often rich in mica and showing complex multi-stage fold structures on a decimetre to metre scale. These zones are comformable with the overall gneiss structure and occur at distances of approximately $80 \mathrm{~m}$ and $150 \mathrm{~m}$, respectively, from the carbonatite intrusion. Their presence and the trace of a conformable $40 \mathrm{~cm}$ thick grey metadyke in the gneiss occurring a few metres from the carbonatite contact (fig. 14) makes the large SEplunging synform fold apparent in the field.

Another micaceous ultramafic rock is found as part of the roof remnants inside the intrusion (fig. 14). It is rusty brown in colour and consists of approximately 90 per cent of phlogopite and olivine, and subordinate clinopyroxene and magnetite. It contains smallscale multi-stage fold structures, and the scattered outcrops of this rock type are believed to be the remains of a once continuous ultramafic layer in the gneiss, similar to those described above.

\section{The carbonatite}

The carbonatite is a light grey to brownish grey rock with crumbly weathering, and is often completely overgrown with vegetation. It varies in grain size from fine grained to pegmatoid, and is typically coarse grained. The carbonate is either calcite alone or a mixture of calcite and dolomite. Massive pegmatoid dolomite layers are seen in a few places. The proportion of non-carbonate minerals varies from a few per cent to approximately 50 per cent of the rock; they are olivine, diopside, phlogopite and magnetite, with lesser amounts of apatite, green spinel, and amphibole. The accessory minerals found are zircon and a number of as yet unidentified phases. Carbonatite varieties occur in which either olivine, phlogopite or magnetite is the dominant non-carbonate phase.

The carbonatite rock is usually flow-banded, especially near its contacts with the country rock. The rock then has a streaky appearance with thin layers and schlieren, between which there are large abrupt variations in modal mineralogy and grain size. In one case inch-scale layering has been found, with a $2 \mathrm{~m}$ thick sequence of $2-20 \mathrm{~cm}$ thick layers of sharply contrasting mineralogy. The flow banding is always parallel to the contacts with the country rocks, and is wrapped around the irregular inclusions. In areas with no inclusions or roof remnants the carbonatite is more massive and homogeneous.

Carbonatite veins up to $20 \mathrm{~cm}$ thick occur in the country rock up to $25 \mathrm{~m}$ from the outer margin. These veins are coarse grained to pegmatoid and their dominating non-carbonate mineral is clinopyroxene. 


\section{Reactions between carbonatite and country rocks}

The intrusion of the carbonatite sheet caused a thorough but relatively localised recrystallisation and metasomatism. Since the country rock spanned from leucocratic silicic to melanocratic ultramafic rocks, a broad range of lithologies have developed within the reaction zones.

The leucocratic gneiss. Up to some metres away from the contact the gneiss recrystallised into a hard, fine-grained, sugary-textured rock, sometimes with scattered millimetre to centimetre large green clinopyroxene crystals. In places the rock contains abundant irregular patches in which the mafic minerals are green (as opposed to the usual black) although the gneiss structure does not seem to be disturbed. Green cross-cutting veins are also found. Weaker fenitisation effects are probably more far-reaching, but the extent of these is not known at present.

Along the immediate contact with the intrusion the gneiss was softened; flakes were spalled off and were bent, folded, sheared and broken and incorporated as inclusions in the carbonatite. At the contacts between silicic rock and carbonatite centimetre to decimetre wide, blackish green, reaction zones of calcic clinopyroxene/amphibole have almost invariably formed, and are fringed towards the silicic rock by a scapolite-rich zone which in extreme cases of metasomatism includes lazurite. Only in a few cases is this mafic layer seen to be missing.

Mafic and ultramafic rocks. Along the outer contact of the intrusion occurs a $1-10 \mathrm{~m}$ broad zone of dark green, coarse-grained ultramafic rock (fig. 14), consisting of green amphibole and clinopyroxene with lesser amounts of phlogopite. Most of this ultramafic material is evidently a reaction product of the contact between carbonatite and gneiss (cf. above). We believe, however, that this contact zone also includes the remains of one of the previously mentioned mafic/ultramafic layers in the gneiss. This would explain its great thickness and the slightly discordant border relations on the eastern flank of the intrusion. A mica-rich layer in the gneiss could also be a zone of weakness and a good lubricating medium for an intruding magma.

Metasomatism of the mica ultramafite in the roof remnants (fig. 14) was limited to carbonate infiltration. There are no apparent silicate reactions, problably because the silicates (olivine, phlogopite, diopside) were stable in both reactants.

Lapis lazuli. Of particular interest is the occurrence of the blue feldspathoidal mineral lazurite, $(\mathrm{Na}, \mathrm{Ca})_{8} \mathrm{Al}_{6} \mathrm{Si}_{6} \mathrm{O}_{24}\left(\mathrm{SO}_{4}, \mathrm{~S}, \mathrm{Cl}\right)_{2}$. It occurs disseminated in intensely transformed contact zones under the roof remnants and in xenoliths. In a few places (fig. 14) compact decimetre thick zones are found which are so rich in lazurite that they must be designated as the classical gemstone lapis lazuli. The Greenland material is not quite as intensely ultramarine blue as that from Afghanistan or Italy, but rather a clear sky blue. The occurrence of lazurite as a product of reaction between carbonatite magma and gneiss is a different type of occurrence of lazurite than those previously described (Hogarth \& Griffin, 1976, 1978). Further, it is the first reported occurrence of this mineral from Greenland. 


\section{Economic potential}

The intrusion must be classified as 'barren'. No accumulations of rare-element minerals like pyrochlore have been found; the amount of apatite is small, and the radiation level of the carbonatite is very low, only slightly higher than the surroundings. Thus the amounts of $\mathrm{Nb}, \mathrm{P}, \mathrm{U}$ and $\mathrm{Th}$ are small, and the intrusion is of no interest from a traditional economic viewpoint.

Lapis lazuli, however, is a well-known semi-precious stone. Several pieces of attractive jewellery have already been made from the Greenland material (Secher et al., 1981). Although the deposit is small it could provide material for home-based, small-scale jewellery production.

\section{Conclusions}

The Tupertalik carbonatite intrusion was formed by a single intrusion of carbonatite magma into a weak zone in the gneiss provided by a comformable amphibolite/ultramafic layer. There are no signs of explosive activity and no late-stage veins and dykes, and the intrusion probably never reached the surface. This contrasts with the subvolcanic character of the Sarfartôq and Qaqarssuk complexes and may be due to the smaller size of the Tupertalik intrusion, or to a deeper level of emplacement, or both.

\section{References}

Gothenborg, J. \& Pedersen, J. L. 1975: Exploration of the Qaqarssuk carbonatite complex 1975, part II. Kryolitselskabet Øresund A/S, unpublished company report.

Hogarth, D. D. \& Griffin, W. L. 1976: New data on lazurite. Lithos 9, 39-54.

Hogarth, D. D. \& Griffin, W. L. 1978: Lapis lazuli from Baffin Island - a Precambrian meta-evaporite. Lithos 11, 37-60.

Secher, K. \& Larsen, L. M. 1980: Geology and mineralogy of the Sarfartôq carbonatite complex, southern West Greenland. Lithos 13, 199-212.

Secher, K., Nielsen, B. L. \& Knudsen, N. Ø. 1981: Grønlands smykkesten. Grønland 1981, 105-152.

A. K.P., 